\title{
Sleeping with strangers - hospitality in colonial Victoria
}

\author{
Associate Professor Ian D. Clark \\ School of Business \\ University of Ballarat
}

\section{Contact details:}

School of Business

University of Ballarat

PO Box 663

Ballarat Vic 3353

Ph. (03) 53279436

Fax: (03) 53279405

Email: i.clark@ballarat.edu.au

\begin{abstract}
The purpose of this article is to describe and document the nascent state of hospitality in colonial Victoria from the 1830s until the gold rushes of the 1850s. The primary source of such an account is the personal journal of a public servant, George Augustus Robinson, the Chief Protector of the Port Phillip Aboriginal Protectorate Department, perhaps the European with the most experience of travelling throughout the Port Phillip District. Accounts from other contemporary sources will be used to complement Robinson's observations.

Where accommodation houses were available they were often crude establishments offering poor fare for travellers. The most comfortable accommodation was to be had on squatting runs, some of which had purpose-built huts for travellers. In some cases hospitality meant sleeping with strangers, sharing beds with one other occupant or sleeping on shakedowns or mattresses on floors with numerous people. However, beyond the limits of settlement, travellers had to make their own arrangements, utilizing abandoned Aboriginal shelters or shepherd huts, pitching their own tents, or simply sleeping on the ground wrapped in a blanket using a saddle or a log for a pillow.
\end{abstract}


The purpose of this article is to describe and document the nascent state of hospitality in colonial Victoria. Richardson's (1999) History of Australian Travel and Tourism, which has a brief discussion on the first inns and hotels in Australia, is one of the few Australian tourism histories to discuss this topic, and this paper will extend his work by focussing more narrowly on the emergence of hospitality in Victoria, when it was the Port Phillip district of New South Wales. Victoria in this context meets John Towner's classification of a ‘tourism era of discovery'. Towner (1996: 140) has noted that 'Discovery eras are often passed over rapidly in studies of tourism where there is a preference for moving on to periods where visitor numbers can be quantified more clearly’. Davidson and Spearritt (2000), for example, in their historical study of tourism in Australia, began from the baseline of the commencement of international tourism to Australia in 1870. They devote very little space to the evolution of a domestic tourism prior to the inclusion of Australia in a round-the-world tour by Thomas Cook.

In studying Victoria's 'tourism era of discovery', the primary source for this reconstruction of the state of hospitality during this time will be the personal journal of a public servant, George Augustus Robinson (1788-1866). Robinson was the Chief Protector of the Port Phillip Aboriginal Protectorate Department from 1839 until early 1850, and was perhaps the European with the most experience of travelling throughout the Port Phillip District (Clark 2000). ${ }^{1}$ Accounts from other contemporary sources will be used to complement his observations. The methodology employed in this paper is that of 'interpretive biography', in that it is the study of individuals and their experiences of nascent hospitality as recounted in first-hand documents (Denzin 1989; Cresswell 1998). These documents will be used to narrate stories of the hardship of early travel in colonial Victoria, the early development of a commercial hospitality 
industry, and the ethic of hospitality that existed on squatting stations. The focus is the collection of experiences, the gathering of stories from these primary documents organized around important themes, and their historical explanation. This is an explicit recognition that the 'past is the theatre of human experience' (Davison 2000, p. 14), and in attempting to consider the early history of hospitality in colonial Victoria we must depend upon our imaginative capacity to look at this world through the eyes of others, primarily through the eyes of the Chief Protector, George Augustus Robinson.

Between 1839 and 1852 Robinson made approximately 30 excursions away from Melbourne where his department was based. His travels took him through almost all of Victoria, and he went as far a field as Twofold Bay, Queanbeyan, Yass, and Gundagai in New South Wales, and Kapunda, Adelaide, Kingston and Mount Gambier in South Australia. He travelled extensively along the Murray River and took every opportunity to follow the track left by Surveyor General TL Mitchell's 1836 Australia Felix expedition. In 1844 he led the first overland expedition that successfully opened a road for wheeled carts from Melbourne to Port Albert. In total, he spent almost three years of his eleven-year appointment travelling.

Victoria, known as the Port Phillip District of New South Wales, prior to separation, had achieved a population of 77,000 non-Aboriginal people by 1850 , yet ten years earlier the population was barely 10,000 (Serle 1963). Apart from the 23,000 residents of Melbourne and its suburbs, population was concentrated in Geelong $(8,000)$, Portland (1,000), Port Fairy (900), and Warrnambool (350). Gippsland held fewer than 2,000 people with several hundred of them in the settlements near Port Albert. Other settlements were farming centres such as Bacchus Marsh, Kilmore, Colac and Kyneton,

\footnotetext{
${ }^{1}$ Citations hereafter will give the date of Robinson's journal entry.
} 
and stopping-places on main pastoral tracks, such as The Grange (Hamilton), Buninyong, Flooding Creek (Sale), and Benalla. Expansion of settled districts was slow, and many squatters opted to move beyond known localities (Powell 1974). In this settlement pattern, accommodation for travellers was commercially available from hotels and inns, and where they had not yet developed, accommodation was generally provided on pastoral stations. In other spaces, travellers had to provide their own accommodation.

During his travels, Robinson stayed at inns where they operated. Squatters and their employees visiting Melbourne with stock and returning with supplies would break their journeys by staying at hotels and inns that sprung up along major routes, and were often the first commercial buildings in surveyed townships. Inns were often established at major river crossings, and in many respects became the nucleus for a cluster of ancillary businesses such as blacksmiths and wheelwrights. Inns in the early 1840s were often crude structures of split slabs, for example the Golden Fleece Inn at Werribee in 1840 was 'a mere hut between the split slabs which stuck in the ground compose the walls a hen with a brood of chickens might find her way out and in’ (Kiddle 1961, p. 83). Though crude, the Golden Fleece was well furnished and gave good fare. Robinson considered Young's Bushman’ Inn, at Sugarloaf Creek, offered poor accommodation: 'soft sugar, no cup bason, but cold water and glass in room, bed, dirty sheets, wood rotton' (Robinson Jnl 19/3/1843). John Clark's Royal Mail Hotel was a simple weatherboard structure. Travel writer William Howitt was not enamoured with Clark's inn on Honeysuckle Creek when he visited in 1852: 'you are not to suppose some English-looking country inn with a honeysuckle porch, but a wooden house, so called from some wretched scrubby and half-dead banksias near it' (Howitt 1972, p. 81). E.M. Curr has provided a detailed description of the Bush Inn at Gisborne: 
The building was of slabs, roofed with shingles in the usual way; its dimensions were about thirty-five feet by twelve, with a skillion in addition in the rear, which ran the whole length of the structure. The exterior and division walls were seven feet high. The ceiling was of white-washed canvas, and a covering of the same material lined the walls in lieu of plaster. The sitting-room into which we found our way, was about fifteen feet long. In the middle of it was a deal table, one end of which was laid with washing utensils for the morning. In the centre of the table was a large brass bell, such as used by criers, and a single tallow candle in a disreputable candlestick, which guttered complacently on to the oilcloth covering. On the mantelpiece were a few gaudy ornaments, Phillises in china with lambs to match, and the figure of a Spanish bull fighter or two, if my memory serves me. There were also in the room four sofas, of the poorest sort, on two of which, beds had been made, the one having an occupant who was already asleep. He was probably a squatter, travelling between his station and town. His boots, hat, and clothes had been thrown on the floor beside him; a tobacco-pouch hung suspended by a leather belt from the head rail of the sofa or bedstead (the one by day and the other by night), and from under his pillow protruded the end of a valise and the butt of a horse pistol (Curr 1965, pp. 13-14).

However, some hotels were substantial two-storeyed structures. One example is the Royal Merrijig Hotel established in Port Fairy in 1844. Squatter William Learmonth stayed there on 27 August 1844: 'I put up on at the Merrijig Hotel, a native phrase for very good, where I was kept awake nearly the whole night by the carousels of 12 or 14 
settlers, or squatters as they are here termed, who seldom meet and consequently are loth to part' (Powling 1980, p. 83). In 1848, John Clark began construction of the Royal Hotel in Seymour. In 1853 it was described as having seven rooms on the ground floor, and ten bedrooms and a sitting-room on the first storey. Attached was a two-story stone building with cellars and storeroom, dining-room capable of seating thirty people, servants' rooms and on the first storey five bedrooms holding from two to four beds each (Martindale 1982).

Curr (1965, p. 15) was critical of the bedding at the Bush Inn at Gisborne, especially of the sofa with blankets and a pungent mutton-bird feather pillow that was his bed. Susan Priestley (1985, p. 50) suggests that a common bed in an inn was 'a wall bunk of slabs with a thin palliasse stuffed with hay or flock, infested with fleas and bugs. Even a thick sheet of bark and some blankets on the floor were more comfortable'. When J.C. Byrne stayed at a small bush hut, at the crossing place of the Ovens River, he slept on a 'sheet of bark and a few blankets that had been spread for his bed' (Whittaker 1963, p. 28). However some of the inns in the interior of Port Phillip were mere grog shanties, like that at Colac, where '... the bar room was always filled with drunken men, many of them just in from a successful shearing season, and the oaths and curses of these infuriated beings strangely co-mingled with the howling and diabolical mirth of drunken and besotted black men and women’ (Kiddle 1961, p. 83).

Where commercial accommodation did not exist, Robinson and other travellers generally received hospitality at private residences, on pastoral stations. Social historian Margaret Kiddle claimed it was often better to sleep by the roadside than be put up at a grog shanty. 'But there was no need to go without shelter, for a welcome was given to nearly all benighted travellers at every home station and out-station hut' 
(Kiddle 1961, p. 84). Katherine Kirkland who experienced living in Western Victoria first hand in the early 1840s has explained that 'In the bush no one is ever allowed to go from a hut without eating, or remaining all night, although an entire stranger' (Kirkland n.d., p. 24). Kiddle considers this tradition of hospitality developed because of the lack of accommodation by the wayside and the general travelling conditions. She considered hospitality could be 'a pretty heavy tax on some of those who have their stations bordering on the principal tracks from the interior to the townships' (Kiddle 1961, p. 84). In January 1839 the Kirkland family arrived at Point Henry, Corio, and having disembarked sought hospitality from David Fisher and his family at Geelong. Katherine Kirkland's recollection of the evening with the Fishers confirms that hosts did not always see hospitality as burdensome:

We got to Mrs Fisher’s about seven o’clock, she received us very cordially. We found tea awaiting us and I there tasted damper for the first time. I liked it very much; it is like bread but closer and heavier. I said to Mrs Fisher that she must think we taken a great liberty in coming in such force upon her; but she did not at all seem to think so. She said she was quite accustomed to have many gentlemen visitors, but she never had had a lady before. I could not at all fancy how she would manage in regard to giving us all beds; however, she soon disposed of us very easily. A bed was made up for me, little Agnes and her maid, on the parlour floor, and all the gentlemen were sent to the wool-shed, to sleep as best they could: fifteen slept in it that night. A few of them had blankets or rugs, but most of them had nothing (Kirkland n.d., p. 4). 
Once settled in her own station, Katherine Kirkland found herself in the same situation, having to accommodate eight settlers who had paid them a visit.

I felt much anxiety about giving them beds; but that was impossible, as we only had one spare mattress. I think they guessed my thoughts, for they told me never to think of giving them anything to sleep on; that no one in this country ever thought of beds for visitors, and that they would manage for themselves. However, I collected all the blankets, pea-jackets, and cloaks I could find and they all slept on the floor. I heard them very merry while making up their beds. Every settler, when riding through the bush, carries either a kangaroo rug or a blanket fastened before him on his horse, so that, wherever he goes, he is provided with his bed; and as it is not an uncommon circumstance for one to lose himself in the bush, and be obliged to sleep at the root of a tree, he then finds his rug or blanket very useful (Kirkland n.d., p. 10).

George Henry Haydon in a 1854 novel titled The Australian Emigrant, based on his life in Western Port and Gippsland from 1840-1845, has given us a description of hospitality.

At his hut, the bushman is the essence of hospitality. Even if you are a stranger to him he would in five minutes possess you with the feeling that the hut and all in it was as much your own as his, and whenever you might feel disposed to resume your journey, he would take special care to examine the state of your provision bag and see you provided with a sufficiency to 
carry you at least to the next station where you would be certain of receiving similar treatment (Haydon in Gunson 1968, p. 42).

It was considered poor manners to offer a pecuniary remuneration in return for services rendered. Haydon noted 'When a gentleman squatter treats you civilly again, don't you ever mistake him for a publican. If you do, darn me, if you won’t get into hot water. There - that's a lesson the old country don't teach. And now, goodbye, and don't forget, whenever you travel this way again, don't you forget to come in and take a shakedown with me’ (Haydon in Gunson 1968, p. 42). James Bonwick was another traveller who was very appreciative of bush hospitality.

The greatest thing that can be said of this country is, that the better classes are exceedingly kind and hospitable, and, considering their isolated lives, not deficient in general information. I am sure we shall always have occasion to remember the kindness of the inhabitants of the bush. Every house, if we had desired it, would have opened itself to us as a home; and but for bush kindness I should, perhaps, not have been writing this (Bonwick 1852, p. 89).

According to Roberts (1975, p. 283), the typical dwellings on a squatting station included a ten-foot by twelve-foot hut, with slab walls and a bark roof. There would typically be one built for the men and a second one, perhaps a trifle larger, for the master of the station. A rough bedstead of sheepskins or possum rugs would suffice, and even of sheets of bark. A squatter's needs were simple: mutton and damper and something to lie on. Some squatting runs constructed huts for travellers: for example, at James Donnithorne's 'St Agnes' run on the Coliban River at Malmsbury, there was 'a 
hut appropriated to visitors - a small place in the yard near the blacksmith's shop, no windows, and the split timber by which the walls are made quite open in the interstices’ (Robinson Jnl 16/1/1840). John Cotton at Doogallook, ensured his residence had a spare room for passing travellers (Billis \& Kenyon 1974, p. 254). At Tyntynder station on the Murray River near present-day Swan Hill, the travellers' hut was situated halfway between the front gate and homestead, some 500 yards from the nearest homestead building (Cerutty 1977).

Frances Kerr recalled the old hut that was home when her family took up Fernyhurst on the Loddon River in northwest Victoria in 1849:

For those days it was considered a good house, and, with the outbuildings pertaining to it, was usually filled with guests of various degree, who took up their abode with us, some for a night or two, others for weeks or months, till they succeeded in making a home for themselves. There were but few inns at that time, and those few were far apart, consequently the hospitality of the squatters was largely drawn upon, and rarely withheld. The bill of fare afforded by the stations was simple, but abundant, and always gave a margin for chance guests, who rarely failed to appear with the setting sun, when large parties of travellers were frequently gathered round the blazing hearth, both in the parlour and kitchen (Kerr 1996, pp. 69-70).

In all his travels through southeast Australia, Robinson was rarely refused hospitality, and on those rare occasions when it was not forthcoming he made a note of the refusals in his private diary. For example, John Pike at Wollert was notorious for his inhospitality and Robinson has described his 1846 encounter with the man facetiously 
known as 'Hungry Pike on the Plain'. Robinson and his two companions, Merrigundidj, a Djadjawurrung man from the Loddon River and Patrick Farrell a Border Policemen, arrived at Pike’s station an hour after sunset:

I had doubts whether this man who goes by name of 'Hungry Pike on the Plain’ would give me accommodation. Sayn said he had refused him and others. ... he first said he could not accommodate, had hunting party and there were ladies, I would not be very comfortable, I ought to have stopped at the inn ... I was distressed when he first expressed an unwillingness not to stay and did not insist, he should ask me, I would rather sleep forest of trees although cold night and my cloak with dray, I was also afraid my horses would break down having come 30 miles. Left the native and pack horse and took Farral that he should hear what passed, when I left him Farral said 'Oh sir, he is well known, he goes by name of 'Hungry Pike on the Plains’ (Robinson Jnl 8/8/1846).

Robinson eventually arrived at GJ Stoke’s Traveller's Rest Inn at Mt Macedon, where they 'had a good meal, read papers, and civil'. Rae-Ellis has suggested that 'there was hostility to the protectors taking too literally the general rule of hospitality to all travellers. Some squatters resented being obliged to provide them with free food and board, because their taxes paid the protectors handsomely for doing their duty' (RaeEllis 1988, p. 234). There seems to be some credibility in this view for Robinson was told that given that the protectorate staff received travelling 'allowances it was wrong for them to trouble the settlers' (Robinson Jnl 22/8/1839). At James Dawson's and George Selby’s 'Corhanwarrabul No. 3' station, near Dandenong, Robinson found himself part of a game between two adjoining station holders. 
It being dark we rode up to request a lodging. This they were not disposed to give. They did not know who I was, nor at this time did I know who they were but I thought them bores and ill-natured. These people made the best excuses, said they were confined for room and had two ladies living with them and recommended me to go back to Anderson's. We did not thank them for their advice. Rode back $2 \frac{1}{2}$ miles to Anderson's it was dark. Anderson began to make excuses. We told him if it was any inconvenience we could sleep in our cloaks, all we required was shelter and fire. ... This man made us as comfortable as his means afforded. He said Dawson's people send every one to him. And I believe he sends them to Dawson, so it is cutting one another (Robinson Jnl 29/8/1840).

There is some irony in Dawson's inhospitality to the Aboriginal Protector as Dawson was later to become a leading advocate of Aboriginal rights in the western District of Victoria, and he and his daughter produced an outstanding ethnography of local Aboriginal people in 1881 (Dawson 1881). On one occasion Robinson was offered accommodation, but the host Henry Hughes at 'Avenel', made the terms of the hospitality very clear:

Our reception at Mr Hughes was of a singular and uncommon character. I rode up to his hut with Mr Dredge. ... Mr Hughes Senior came out. I introduced myself to him as Mr Robinson, the Chief Protector, and at the same time mentioned Mr Dredge as the Assistant Protector of the district. We were still mounted. Mr Hughes in rather a haughty and rough tone said, 'I can’t receive you as protectors, gentlemen. I don't acknowledge the 
office’. A pause then ensued. Mr Dredge asked [if] it was far to the next station. The sun was setting. Mr Hughes said Mr Templeton's [Seven Creeks, south of Euroa], 25 miles, was the nearest east, the way we were going, and then said that as travellers we were welcome, but not as protectors. We said we should not fall out on that account. He said he wished the subject to be dropped, and we dismounted. Our horses were taken in charge and tethered to grass after first feeding them with corn. He wished the subject dropped. Silly young man he it was that commenced it and I was the last person who would quarrel on such a subject, because I had to learn what mischief protectors had done him (Robinson Jnl 17/4/1840).

Kiddle has argued the lack of bedding was never an issue, as 'most people travelling ... generally carry a blanket with them in which they roll themselves in a corner of the hut if they cannot be accommodated with a bed: a bed in the bush is merely a coarse erection of sticks along the side walls of the hut, on which lay a mattress, or perhaps only a little dried grass or reeds' (Kiddle 1961, p.84.). The morning after, provision was made of 'a basin ... on a stool at the door, a cloth beside it and a pail of clean water. Everyone goes out there and washes each one helping himself to water out of the pail. ... If a traveller did not seem to be of the proper social status he would be directed to find a bed in the men's hut. Indeed, whatever his status, he was glad to find shelter at an outlying hut if he was not within easy distance of a home station by nightfall. ... However uneasy the bed it was shared with him' (Kiddle 1961, p. 84).

The Aboriginal Protectorate, itself, was not immune from providing hospitality to travellers passing through Protectorate stations. At the Goulburn Station on the 
Goulburn River, at what is now Murchison, the medical officer in charge, Dr James Horsburgh threatened resignation in 1848 if he did not receive an extra ration allowance: 'If I am not to be allowed extra rations for myself also for travellers, I have no alternative but resign my situation as my salary is a mere drop in the bucket' (Horsburgh 25/1/1848). Horsburgh explained that there were very few nights when the station did not have travellers staying at the station: 'The number calling lately has quite annoyed Mrs H. who is run off her feet cooking for so many’ (Horsburgh 25/1/1848).

Where accommodation was limited, Robinson often had to share a bed with another man, or sometimes share with a number of men a shakedown which was a mattress placed on the floor. In the winter of 1839, William and George Russell visited Henry Gibb at Chatworth. That night they found that 'Henry's bed accommodation was not very extensive; the three of us were packed into a bunk which would have not been too roomy for two' (Doody 1983, p. 5). At RW Murdoch’s 'Ghin Ghin’ station on the Goulburn River near Yea, Robinson noted that 'they are short of things to accommodate travellers, I and Dredge had to sleep in one bed, a thing I detest, but there was no alternative' (Robinson Jnl 4/4/1840). At George McKilllop’s 'Castle Hill' run on the Broken River, there was a similar shortage of bedding: 'Dredge and McK stowed away in a narrow berth, I slept on a stretcher by myself, more congenial to my feelings' (Robinson Jnl 9/5/1840). The following day at Peter Stuckey’s run, Robinson shared a shakedown: 'We had a shakedown in the fortress, it was about 12 by 8 , in which the four white men, the black Stucky, Dredge and myself [slept], large [enough] to stow eight persons' (Robinson Jnl 10/5/1840). At David Waugh's station on the Devil's River, at Delatite, Robinson was provided with tea and damper and fried mutton: 'we made a hearty meal and being fatigued and famished with a shakedown we retired to rest, Mr Dredge and I slept together' (Robinson Jnl 11/5/1840). At Young's station at 
Mt Battery, Robinson and Dredge were provided with 'a narrow sleeping berth, scarcely large enough for one, into which I and Dredge stowed ourselves. I had but little rest this night' (Robinson Jnl 12/5/1840). Fortunately, we have Dredge's account of his experiences, which serve as a useful counterpoint. Dredge wrote in his diary, 'in consequence of a monopoly of clothing by my distinguished accomplice, I was cold and uncomfortable' (Dredge 12/5/1840 in Dredge 1998, p. 20). It is difficult to learn much about travellers sharing beds and shakedowns, and this study of this phenomenon is reminiscent of Malcolmson's observation (in Towner 1996, p. 29) that 'the closer we approach the most commonplace experiences ... the more meagre our information becomes'.

Once away from commercial accommodation and the hospitality of squatting stations, travellers had to fend for themselves and some of Robinson's descriptions of his sleeping arrangements when beyond settled districts are reminiscent of vintage Hollywood westerns. When travelling with a phaeton, Robinson would often sleep in the carriage, or pitch a tent if he was carrying one. When he had neither tent nor carriage he would make do with what was available: 'took a saddle for a pillow and lay down under a cherry tree till morning' (Robinson Jnl 16/5/1841); and sometimes a log served as a pillow: 'We selected a large gum tree, beneath the umbrageous branches of which we kindled a fire and, having selected a log for a pillow, lay ourselves down to rest and, having no food, went supper-less to bed, having previously collected some fuel and tethered our horses’ (Robinson Jnl 5/4/1840). Samuel Rawson has described the discomfort of sleeping under a dray during inclement weather in January 1839 in south Gippsland: 
Jamieson \& I crawled under the dray, the bottom boards of which were 6 inches apart, we spread our cloaks \& blankets over it, but in about 5 minutes they were all soaked thro, it was so hot we could not bear any clothes on, the Thermometer being about $95^{\circ}$ We laid thus in our shirts till about 2 oClock in a perfect deluge, every time I fell asleep I was awoke by Jamieson who was thrashing away with the branch of a tree to keep the mosquitoes off, at that hour the weather changed \& it became deadly cold the rain changed into a mixture of hail, rain and snow our fire was gone out, every particle of clothing we had, was wet through, \& when I awoke at daylight I never felt so cold \& miserable in my life ...(Gunson 1968, p, 21).

On those occasions when he was travelling with Aboriginal people, they sometimes arranged Robinson's berths: for example, one evening they 'made me a rude screen of boughs' (Robinson Jnl 10/4/1843); 'slept in open air, few boughs for covering' (Robinson Jnl 22/4/1844); 'Natives made me a willam, good one’ (Robinson Jnl 29/4/1844; a willam is a bark shelter). If it looked like it would rain the shelter would be made from bark if it was available, if not, a screen of boughs was commonplace. For example, at a camp near the Glenelg River, Robinson slept under a bough tent, with a sheep skin as a mattress, and a folded blanket as a covering, and put his saddle over his head (Robinson Jnl 4/5/1845); Robinson slept in a hollow tree on 4 May 1845, near Lake Mundi in far southwest Victoria, and though it rained all night he remained dry. At 'Newlands' station near Apsley, Robinson commented that there were snakes around the tent, and the one in his bed was killed (Robinson Jnl 8/5/1845). On the Murray River on 9 May 1846, and without a tent, Robinson simply wrapped himself in his blanket and lay on the ground in the star spangled camp and the moon near a full orb brightly shining over me’ (Robinson Jnl 9/5/1846). Lady Jane Franklin has left an 
account of sleeping in the outdoors, and her description reveals that large groups arranged themselves into smaller groups centred on night fires, and women had their own fire some distance from the men’s groups.

I look back upon many nights spent in the bush with much pleasure, thanks to the beauty of the climate, and the effects produced by the usual arrangements of an encamping party, and especially by its sub-divisions. Ours was of a somewhat mixed character, and grouped itself into small knots, each having its own fire. This seems the ordinary, if not invariable, practice, and as the solitary wayfarer is generally thankful to join others who may be going his way, encampments often include individuals not belonging to the original party. This evening, although it was evident that a hot wind was coming on, five or six fires were soon blazing near to each other; one, however, the ladies’ fire, being the most distant, and simply within hail of the rest. The light cart was brought within a few feet of the chief fire, the ladies’ fire beside which we had been sitting. The back was turned towards it, with the shafts resting upon the ground. Between these a blanket was fastened so as to form a back to the bed; the wheels were interlaced with boughs to shelter us from any passing breeze; on the earth were spread our cloaks and a kangaroo skin rug, and finally our carpet bags were to serve as pillows (Rawnsley 1923, p. 95-96).

This paper has attempted to show the humble origins of the hospitality industry in Victoria in the 1830s and 1840s. This early period of Victoria's colonial history complies with Towner's 'tourism era of discovery', a period generally neglected in histories of Tourism in Australia. The primary source for this account has been the 
private journal of a public official, whose duties often took him beyond settled colonial Victoria and into Aboriginal lands. He is probably the most travelled official during this early period and as such provides unique insights into Victoria's nascent hospitality.

Where accommodation houses were available they were often crude establishments offering poor fare for travellers. Contemporary accounts confirm that away from inns and hotels, there was a distinct spatial organization of hospitality on pastoral stations where comfortable accommodation was to be had in purpose-built huts for travellers, or rooms set aside for travellers. However, in some cases hospitality meant sleeping with strangers, sharing beds with one other occupant or shakedowns with numerous people. However, beyond the limits of settlement travellers had to make their own arrangements, utilizing abandoned Aboriginal shelters or shepherds' huts, pitching their own tents, or simply sleeping on the ground wrapped in a blanket using a saddle or a log for a pillow. 


\section{References}

Billis, R.V. \& Kenyon, A.S. (1974). Pastures New An Account of the Pastoral Occupation of Port Phillip. Melbourne: Stockland Press.

Bonwick, J. (1852). Notes of a Gold Digger, and Gold Diggers Guide. Melbourne: Connebee.

Bossence, W.H. (1965). Murchison. Melbourne: The Hawthorn Press.

Cerutty, A.M. (1977). Tyntynder A Pioneering Homestead and Its Families. Kilmore: Lowden Publishing.

Clark, I.D. (2000). The Journals of George Augustus Robinson, Chief Protector, Port Phillip Aboriginal Protectorate, 1839-1852, Six Volumes. Clarendon: Heritage Matters.

Clark, I.D. (2001). The Papers of George Augustus Robinson, Chief Protector, Port Phillip Aboriginal Protectorate, Vol. 3, Miscellanea. Clarendon: Heritage Matters.

Cresswell, J.W. (1998), Qualitative Inquiry and Research Design, Thousand Oaks, CA: Sage.

Curr, E.M. (1965). Recollections of Squatting in Victoria Then called the Port Phillip District (From 1841 to 1851). Carlton: Melbourne University Press. [First published 1883, Melbourne: George Robertson].

Davidson, J. \& P. Spearritt, P. (2000), Holiday Business - Tourism in Australia since 1870. Melbourne: Miegunyah Press.

Davison, G. (2000), The Use and Abuse of Australian History, Crows Nest: Allen \& Unwin.

Dawson, J. (1881), Australian Aborigines ... Melbourne: George Robertson.

Denzin, N.K. (1989), Interpretive Biography, Newbury Park, CA: Sage.

Doody, K.C. (1983). The Making of our Town Camperdown. Camperdown: Town of Camperdown Council.

Dredge, R. (1998). ‘An awful silence reigns': James Dredge at the Goulburn River' in The La Trobe Journal, (pp. 17-26) No. 61.

Gunson, N. (1968). The Good Country Cranbourne Shire. Melbourne: Cheshire, Melbourne.

Horsburgh, J. 25/1/1848 in VPRS 11 Registered Inward Correspondence to the Superintendent, Port Phillip District relating to Aboriginal Affairs, 1839-51, Public Record Office Victoria, Unit 2, Item 53.

Howitt, W. (1972). Land, Labour and Gold or Two Years in Victoria with Visits to Sydney and Van Diemen's Land. Kilmore: Lowden Publishing Company. [First published 1860, London: Longman, Green, Longman, and Roberts].

Kelly, W. (1977). Life in Victoria, or Victoria in 1853, and Victoria in 1858 .... Kilmore: Lowden Publishing Co. [First published 1859, London: Chapman \& Hall].

Kerr, F. (1996). Glimpses of life in Victoria by 'A Resident'. Melbourne: Melbourne University Press. [First published 1872, Edinburgh: Edmonstan \& Douglas]

Kirkland, K. (n.d.). Life in the Bush. Trawalla: KW Mackenzie [undated reprint of 1845 article from Chambers Miscellany].

Kiddle, M. (1961). Men of Yesterday A Social History of the Western District of Victoria 1834-1890. Melbourne: Melbourne University Press.

Martindale, H.G. (1982). New Crossing Place The Story of Seymour and its Shire. Seymour: Shire of Seymour.

Powell, J.M. (1974). 'The squatting occupation of Victoria, 1834-60' in Powell J.M. (ed.) The Making of Rural Australia (pp. 25-38). Melbourne: Sorrett Publishing.

Powling, J.W. (1980). Port Fairy The First Fifty Years. Melbourne: William Heinemann.

Priestley, S. (1984). Making Their Mark. Melbourne: Fairfax, Syme \& Weldon Associates.

Rae-Ellis, V. (1988). Black Robinson protector of Aborigines. Melbourne: Melbourne University Press.

Rawnsley, W.F. (ed.) (1923) The Life, Diaries and Correspondence of Jane Lady Franklin 1792-1875, London: Erskine Macdonald.

Richardson, J.I. (1999). A History of Australian Travel and Tourism. Elsternwick: Hospitality Press.

Robert, S.H. (1975). The squatting Age in Australia 1835-1847. Melbourne: Melbourne University Press.

Serle, G. (1963). The Golden Age A History of the Colony of Victoria, 1851-1861. Melbourne: Melbourne University Press.

Towner, J. (1996). An Historical Geography of Recreation and Tourism in the Western World 1540-1940. Chichester: John Wiley \& Sons.

Whittaker, D.M. (1963). Wangaratta. Wangaratta: Wangaratta City Council. 